\title{
Synthesis of Nanosized Ceria-Zirconia Solid Solutions by a Rapid Micro- wave-Assisted Combustion Method
}

\author{
Benjaram M. Reddy*, ${ }^{*}$, Gunugunuri K. Reddy ${ }^{1}$, Lankela H. Reddy ${ }^{1}$ and Ibram Ganesh ${ }^{2}$ \\ ${ }^{1}$ Inorganic and Physical Chemistry Division, Indian Institute of Chemical Technology (IICT), Uppal Road, Hyderabad- \\ 500 607, India \\ ${ }^{2}$ Centre for Advanced Ceramics, International Advanced Research Centre for Powder Metallurgy and New Materials \\ (ARCI), Balapur (PO), Hyderabad - 500005, India
}

\begin{abstract}
By adopting a simple cost effective microwave-assisted synthesis methodology, nanosized ceria-zirconia solid solution (MW) has been prepared. For comparison purpose, ceria-zirconia solid solution with the same composition was also synthesized by a coprecipitation method $(\mathrm{CP})$ and calcined at $773 \mathrm{~K}$. Both the samples were examined by different characterization techniques namely, X-ray diffraction, Raman spectroscopy, X-ray photoelectron spectroscopy, transmission electron microscopy, BET surface area and other methods, and evaluated for CO oxidation activity. XRD studies revealed formation of monophasic $\mathrm{Ce}_{0.5} \mathrm{Zr}_{0.5} \mathrm{O}_{2}$ solid solution in the $\mathrm{MW}$ sample and $\mathrm{Ce}_{0.75} \mathrm{Zr}_{0.25} \mathrm{O}_{2}$ solid solution in the $\mathrm{CP}$ sample. TEM studies showed the presence of nanometre sized particles with broad particle size distribution in the sample prepared by microwave method. Raman spectroscopy and oxygen storage capacity measurements suggested the presence of more oxygen vacancies and lattice defects in the MW sample. XPS studies indicated a high reducibility and surface enrichment of $\mathrm{Ce}^{3+}$ ions in the MW sample. Higher $\mathrm{CO}$ oxidation activity and lower light off temperature was observed for the microwave synthesized sample in comparison to that of coprecipitated sample.
\end{abstract}

Keywords: Nanomaterials, microwave synthesis, ceria-zirconia solid solution, catalyst characterization, CO oxidation.

\section{INTRODUCTION}

Due to increasing concern about environmental impact, there has been tremendous interest in developing new processes that both reduce energy consumption and minimize pollution in chemicals synthesis and processing. Heterogeneous catalysis is the key to successful development of the so-called "green chemistry" since it is widely used to reduce emissions from automobile and stationary combustion sources. In recent years, numerous catalysts have been investigated for $\mathrm{CO}$ oxidation at low temperatures due to its extensive applications in various domains such as removal of $\mathrm{CO}$ traces in enclosed atmospheres, automotive emission control, preferential oxidation of $\mathrm{CO}$ for proton exchange membrane fuel cells, and so on [1]. Neutralization of gas emissions containing the $\mathrm{CO}$ and toxic organic compounds by catalytic combustion is one of the widely used methods based on complete oxidation over an appropriate catalyst system in the presence of oxygen or ozone [2-6]. Catalyst systems based on precious metals are well-known for oxidation reactions with high activity and stability, and are widely used for CO oxidation. However, owing to the soaring cost of precious metals and their sensitivity to sulfur poisoning, attention has been given to improve the catalytic performance of metal oxide based catalysts. Due to the peculiarity of ceria that acts as an oxygen storage and release material, the three-way-catalysts (TWC) are employed for the exhaust

*Address correspondence to this author at the Inorganic and Physical Chemistry Division, Indian Institute of Chemical Technology (IICT), Uppal Road, Hyderabad - 500 607, India; Tel: +91 40 27160123; Fax: 9140 27160921; E-mail: bmreddy@iict.res.in,mreddyb@yahoo.com treatment in gasoline-fuel vehicles to achieve simultaneous control of $\mathrm{CO}$, hydrocarbons and $\mathrm{NO}$ emissions [7]. The primary feature for catalytic applications is the ability of $\mathrm{CeO}_{2}\left(\mathrm{Ce}^{4+}\right)$ to be reversibly reduced to $\mathrm{Ce}_{2} \mathrm{O}_{3}\left(\mathrm{Ce}^{3+}\right)$ at moderate temperatures $(<773 \mathrm{~K})$, involving oxygen take-up from lean fuel gas and oxygen delivery during fuel-rich conditions [7]. This characteristic property allows controlling the reaction environment that can be kept within a narrow composition range in order to ensure the effective catalytic removal of all the pollutants. However, the modern TWCs comprising of ceria-zirconia solid solutions demonstrate enhanced oxygen-storage properties with respect to ceria alone and are extensively investigated [8]. Most of the recent research on TWCs is devoted to the development of new preparation methods for ceria-zirconia that should comply with the zero emission demand of the forthcoming international rules.

As such several preparation methods were employed to make ceria-zirconia solid solutions. Each method has its own advantages and disadvantages. Compared with the conventional methodologies, microwave synthesis route possess the advantages of very short reaction times and production of minute particles with narrow size distribution and high purity. Because of its unique thermal heating mechanism, microwave energy heats the entire sample volume almost homogeneously. The surface of sample radiates energy, resulting in high temperature at the interior of the sample. The effect of heating is created by the interaction of the dipole moment of the molecules with the high frequency electromagnetic radiation $(2.45 \mathrm{GHz})$. Water has a very high dipole moment which makes it one of the best solvents for micro- 
wave assisted reactions $[9,10]$. In the present investigation, a ceria-zirconia solid solution was prepared by microwaveassisted solution combustion method and a reference ceriazirconia was also prepared by a conventional coprecipitation method and calcined at $773 \mathrm{~K}$. The prepared samples were examined by XRD, Raman, TEM, XPS and BET surface area techniques, and evaluated for $\mathrm{CO}$ oxidation activity at normal atmospheric pressure.

\section{EXPERIMENTAL}

Nitrates were chosen as precursors to prepare ceriazirconia (1:1 molar ratio) solid solutions by microwaveassisted combustion method. The required quantities of cerium(III) nitrate (Aldrich, AR grade) and zirconyl(IV) nitrate (Fluka, AR grade) were dissolved separately in deionised water and mixed together in a Pyrex glass dish $(150 \mathrm{~mm}$ diameter $\times 80 \mathrm{~mm}$ height). A stoichiometric quantity (as per the concept used in propellant chemistry) of solid urea (Fluka, AR grade) was added to the aforementioned mixture solution and stirred rigorously to obtain a clear solution. The dish containing the reaction mixture was introduced into a modified domestic microwave oven (BPL, India Limited, BMO-700T, $2.54 \mathrm{GHz}, 700 \mathrm{~W}$ ). Initially, the solution boils and undergoes dehydration followed by decomposition and spontaneous combustion with the evolution of large amounts of gases, including $\mathrm{N}_{2}, \mathrm{CO}_{2}$ and $\mathrm{H}_{2} \mathrm{O}$ along with some traces of $\mathrm{NH}_{3}$ and $\mathrm{NO}_{2}$ followed by a spontaneous flame resulting in a light yellow residual mass. The entire process of liquid evaporation, thickening of the solution and combustion in the microwave oven took around $40 \mathrm{~min}$ to produce highly voluminous ceria-zirconia powders. Three to four experiments were conducted under identical conditions to check for reproducibility. Properties of all the synthesized powders were found to be identical. Ceria-zirconia (1:1 mole ratio) solid solution was also prepared by a coprecipitation method with dilute ammonium hydroxide $(0.1 \mathrm{M})$. Detailed preparation procedure has been described elsewhere [11].

XRD patterns were recorded on a Bruker (Karlsruhe, Germany) D8 advanced system using a diffracted beam monochromated $\mathrm{Cu} \mathrm{K} \alpha(0.15418 \mathrm{~nm})$ radiation source. The intensity data were collected over a $2 \theta$ range of $3-80^{\circ}$ with a $0.02^{\circ}$ step size. Crystalline phases were identified by comparison with the reference data from the International Centre for Diffraction Data (ICDD). The average crystallite size of the oxide phases was estimated employing Scherrer equation and considering the XRD data of most prominent line [12]. The lattice parameters were calculated by a standard cubic indexation method using the intensity of the most prominent peak (111) [13]. The $\mathrm{N}_{2}$ BET surface areas of the powders were determined by $\mathrm{N}_{2}$ adsorption at liquid nitrogen temperature using a Micromeritics Gemini 2360 instrument. Prior to analysis, samples were oven dried at $393 \mathrm{~K}$ for $12 \mathrm{~h}$ and flushed with Argon gas for $2 \mathrm{~h}$. The Raman spectra were recorded on a triple subtractive Jobin Yvon T64000 Raman spectrometer equipped with a liquid-nitrogen-cooled chargecoupled device (CCD) detector. The TEM studies were made on a Philips CM 20 instrument equipped with a slow-scan CCD camera and at an accelerating voltage of $200 \mathrm{keV}$. Samples were sonically dispersed in ethanol and deposited on a carbon-coated copper grid before examination. The XPS measurements were performed using a CEMUP-LAS (SECALAB 200A) spectrometer by using Mg K $\alpha$ (1253.6
eV) radiation as the excitation source. The charging of the powders was corrected by setting the binding energy of the adventitious carbon ( $\mathrm{C} \mathrm{1s}$ ) at $284.6 \mathrm{eV}$. The analysis was done at a pressure of $10^{-6} \mathrm{~Pa}$. Quantification of the atomic ratios was achieved by determining the elemental peak areas, following a Shirley background subtraction by the usual procedures documented in the literature [14]. The amount of $\mathrm{Ce}^{3+}$ present in the samples was determined by using following formula

$$
\text { Amount of } \mathrm{Ce}^{3+}(\%)=\frac{\text { Peak area of } \mathrm{v}^{\prime}+\text { Peak area of } \mathrm{u}^{\prime}}{\text { Total area of the spectra }} \times 100
$$

Where $v^{\prime}$ and $u^{\prime}$ are characteristic peaks of $\mathrm{Ce}^{3+}$

The oxygen storage/release capacity (OSC) was examined by oxygen release characteristics of the powders in the temperature range $573-1073 \mathrm{~K}$. The change in the weight of the sample was scrutinized by thermogravimetry (TG) method under cyclic heat treatments in flowing nitrogen and dry air. A commercial Mettler Toledo TG-DTA instrument was employed for this purpose. The heat cycle consisted of heating the sample to $1073 \mathrm{~K}$ in $\mathrm{N}_{2}$, cooling down to $423 \mathrm{~K}$ in dry air, and again heating to $1073 \mathrm{~K}$ in $\mathrm{N}_{2}$ environment. All heating and cooling rates were at $5 \mathrm{~K} \mathrm{~min}^{-1}$. The weight loss of the sample during second heating cycle was used to measure the oxygen release properties [13]. CO oxidation was conducted in a fixed-bed microreactor under normal atmospheric pressure at 300-773 K under a heating ramp of 5 $\mathrm{K} \mathrm{m^{-1 }}{ }^{-1}$. About $100 \mathrm{mg}$ catalyst sample $(250-355 \mu \mathrm{m}$ sieve fraction) diluted with quartz particles of the same sieve fraction was placed in a quartz reactor for evaluation. The $\mathrm{CO}$ and $\mathrm{CO}_{2}$ gas concentrations were measured using an Uras 14 infrared analyzer module, and the $\mathrm{O}_{2}$ concentration was measured using a Magnos 16 analyzer (Hartmann \& Braun). Prior to oxidation of $\mathrm{CO}$, catalysts were heated to $773 \mathrm{~K}$ in $10.2 \% \mathrm{O}_{2} / \mathrm{Ar}$ gas mixture, using a heating ramp of $10 \mathrm{~K}$ $\min ^{-1}$, and kept at the final temperature for $1 \mathrm{~h}$. The oxidized sample was then purged in argon and cooled to the desired starting temperature. The $\mathrm{CO} / \mathrm{O}_{2}$ reactant feed ratio was 1 , and partial pressures of $\mathrm{CO}$ and $\mathrm{O}_{2}$ were in the range of 10 mbar [15].

\section{RESULTS AND DISCUSSION}

X-ray powder diffraction patterns of the two differently synthesized samples in the present investigation are shown in Fig. (1). As can be noted from this figure, formation of cubic fluorite type phase with the composition $\mathrm{Ce}_{0.5} \mathrm{Zr}_{0.5} \mathrm{O}_{2}$ (PDFICDD 38-1436) has been manifested in the case of microwave (MW) synthesized sample. The conventional coprecipitated (CP) sample calcined at $773 \mathrm{~K}$ exhibited poor crystallinity. Only broad diffraction lines due to cubic fluorite type phase with the composition $\mathrm{Ce}_{0.75} \mathrm{Zr}_{0.25} \mathrm{O}_{2}$ (PDF-ICDD 28-0271) has been established. The observed more zirconium incorporation in the MW sample is primarily due to progressive increase of $\mathrm{Zr}^{4+}$ content into the ceria unit cell at higher preparation temperatures. Since the ionic radius of $\mathrm{Zr}^{4+}(0.84 \AA)$ is smaller than $\mathrm{Ce}^{4+}(0.97 \AA)$ incorporation of zirconium ion into the ceria unit cell also leads to decrease of cell parameter and shrinkage of the lattice [16]. Within the detection limits of XRD technique there was no evidence about the presence of $\mathrm{t}-\mathrm{ZrO}_{2}$ or $\mathrm{m}-\mathrm{ZrO}_{2}$ phases. It appears that the remaining zirconia, in the case of $\mathrm{CP}$ sample, is 
mostly in an amorphous form probably located in the grain boundaries.

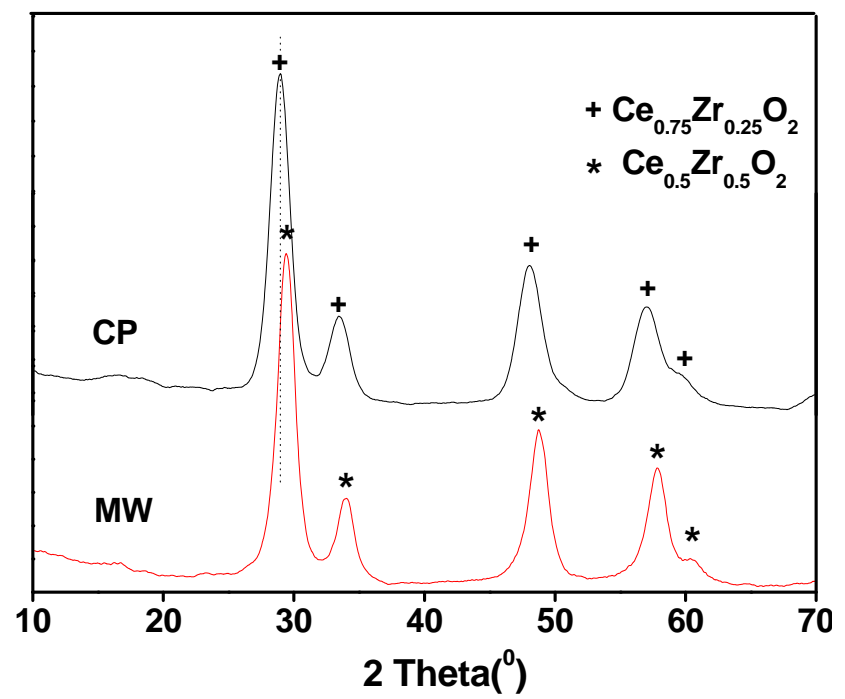

Fig. (1). X-ray powder diffraction patterns of ceria-zirconia solid solutions (MW: prepared by microwave method; CP: prepared by coprecipitation method).

The crystallite size, cell "a" parameter, $\mathrm{N}_{2}$ BET surface area and OSC in terms of oxygen vacancy concentration pertaining to MW and CP samples are presented in Table $\mathbf{1 .}$ MW sample exhibited relatively less specific surface area than CP sample. This is mainly due to exposure of the sample to higher temperatures during preparation, however for a shorter duration. It is known that specific surface area is not the only parameter that determines the catalytic efficiency of ceria-based solid solutions because in cerium oxide weakly bound active oxygen species are present in the bulk rather than on the surface $[17,18]$. Ceria crystallizes in cubic fluorite structure and exposes the thermodynamically most stable (111) surface. This surface is the oxygen termination of the stoichiometric O-Ce-O tri layers stacked along the (111) direction and also corresponds to major fraction of the active surface in catalytic nanocrystallites [19]. Using the most intense line (111) of the XRD pattern, cubic indexation and calculation of unit cell parameters have been carried out. There is decrease in the cell "a" parameter in case of MW (5.30 $\AA$ ) sample compared to the CP (5.35 $\AA$ ) sample. It is a clear indication for penetration of more $\mathrm{Zr}^{4+}$ cations into the ceria core fcc lattice (space group $\mathrm{Fm} 3 \mathrm{~m}$ ) in case of $\mathrm{MW}$ sample which is inline with the XRD results [20].

Fig. (2) shows the Raman spectra of the two samples investigated in the present study. As shown in Fig. (2), both samples show a strong band at 470 or $468 \mathrm{~cm}^{-1}$ and a less prominent broad band at $600 \mathrm{~cm}^{-1}$. The band at $468 \mathrm{~cm}^{-1}$ is due to the $F_{2 g}$ vibration of the fluorite-type lattice [21]. It can be viewed as a symmetric breathing mode of the oxygen atoms around the cerium ions [22]. The slight shift in the Raman frequency to higher wave numbers in case of MW sample could be due to incorporation of more zirconium into the ceria lattice when compared to the CP sample as evidenced by XRD results. As presented in Fig. (2), the Raman band at $470 \mathrm{~cm}^{-1}$ is intense in the case of MW sample. It is known from the literature that the intensity of Raman band depends on several factors including the grain size and morphology [23]. Therefore, it is quite obvious that sintering of samples at higher preparation temperatures increases the intensity of the $F_{2 g}$ band. It is also known that sintering of samples under high-temperature conditions can lead to the formation of oxygen vacancies, which perturb the local M-O bond symmetry leading to the relaxation of symmetry selection rules. The presence of a weak and less prominent broad band near $600 \mathrm{~cm}^{-1}$ can be attributed to a non-degenerate longitudinal optical (LO) mode of ceria which arises due to relaxation of symmetry rules, which in turn linked to oxygen vacancies in the ceria lattice $[21,24,25]$. In particular, the substitution of zirconium into the ceria lattice with an increase in temperature gives rise to oxygen vacancies, which are responsible for the emergence of this band [26]. This band is more intense in the case of MW sample, which indicates incorporation of more zirconium into the ceria lattice and formation of more oxygen vacancies in MW sample. There is also another band at $305 \mathrm{~cm}^{-1}$ in MW sample. As per the literature, this can be attributed to displacement of oxygen atoms from their ideal fluorite lattice positions [27]. As per the literature reports, this band further reveals the presence of $t^{\prime \prime}$ phase, which could not be identified by XRD. The presence of this phase is expected to improve the catalytic performance of this solid solution [28, 29]. The presence of this band and more intense band at $605 \mathrm{~cm}^{-1}$ has also clearly reflected in its enhanced oxygen vacancy concentration as determined by the OSC measurements (Table 1).

To understand the extent of interaction of zirconia with ceria, the synthesized samples were subjected to XPS analysis. The observed binding energy values are presented in Table 2. The $\mathrm{O} 1 \mathrm{~s}$ peak is generally broad and complicated (not shown), because of the non-equivalence of surface $\mathrm{O}$ ions. As per the literature, the $\mathrm{O}$ ions in pure $\mathrm{CeO}_{2}$ exhibit intense peaks at 528.6, 528.8, 529.6 and $530.1 \mathrm{eV}$ respectively [30-33]. The $\mathrm{O} 1 \mathrm{~s}$ binding energy value reported for $\mathrm{ZrO}_{2}$ is $530.6 \mathrm{eV}$ [34]. The $\mathrm{O} 1 \mathrm{~s}$ binding energies of $\mathrm{CP}$ and MW samples are observed at 530.1 and $530.3 \mathrm{eV}$, respectively. The broadening of the peak and slight increase in the binding energy value, in case of MW sample could be considered as an evidence for the incorporation of more zirconium into the $\mathrm{CeO}_{2}$ lattice. As shown in Table 2, the binding

Table 1. Crystallite Size, Cell Parameter, BET Surface Area and Oxygen Storage Capacity Values of Ceria-Zirconia Solid Solutions Synthesized by Microwave Combustion (MW) and Coprecipitation (CP) Methods

\begin{tabular}{|c|c|c|c|c|}
\hline MW & 12.7 & 5.30 & 56 & 278 \\
\hline
\end{tabular}




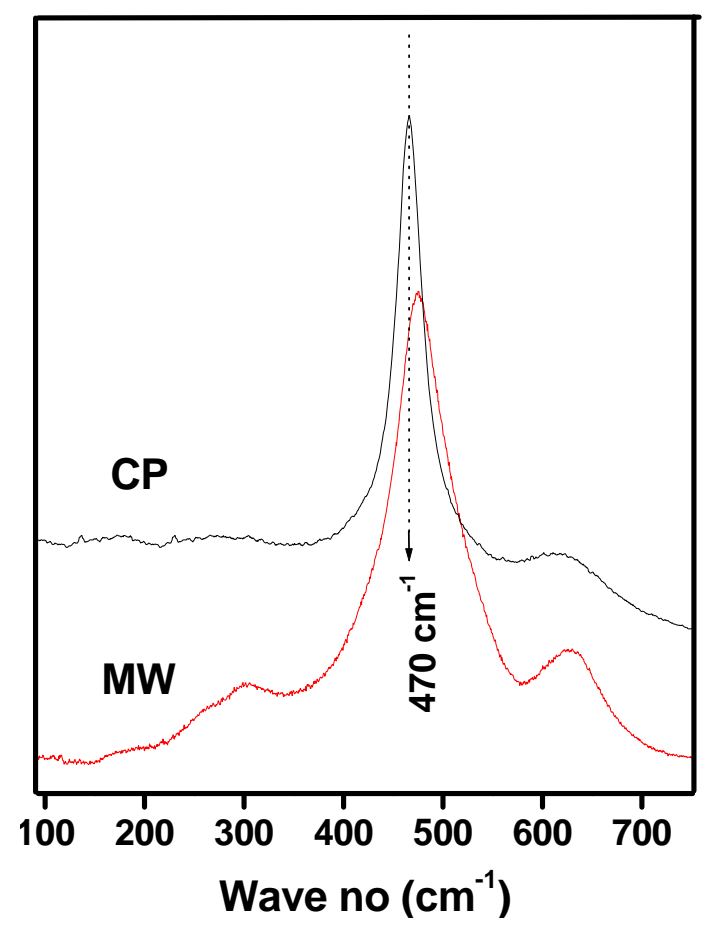

Fig. (2). Raman spectra of ceria-zirconia solid solutions (MW: prepared by microwave method; $\mathrm{CP}$ : prepared by coprecipitation method).

energy of the $\mathrm{Zr} 3 \mathrm{~d}$ photoelectron peak ranged between 182.2 and $182.6 \mathrm{eV}$, which agrees well with the values reported in the literature $[14,35]$. The core level spectra of $\mathrm{Zr}$ $3 \mathrm{~d}$ in the case of the MW sample showed broadening along with shift toward higher binding energy, indicating the incorporation of more zirconium into the ceria lattice. Ce $3 \mathrm{~d}$ spectra of both the samples prepared in the present study are shown in Fig. (3). The assignment of $\mathrm{CeO}_{2} 3 \mathrm{~d}$ photoelectron peaks is ambiguous, because of the complex nature of the spectra, which occur not only because of multiple oxidation states but also because of the mixing of $\mathrm{Ce} 4 \mathrm{f}$ levels and $\mathrm{O}$ $2 \mathrm{p}$ states during the primary photoemission process. Two sets of spin-orbital multiplets, corresponding to the $3 \mathrm{~d}_{3 / 2}$ and $3 \mathrm{~d}_{5 / 2}$ contributions are labeled as $\mathrm{u}$ and $\mathrm{v}$ respectively. The peaks labelled $\mathrm{u}^{\prime}$ and $\mathrm{v}^{\prime}$ are corresponding to $\mathrm{Ce}^{3+}$ oxidation state and the remaining peaks are corresponding to $\mathrm{Ce}^{4+}$ oxidation state [36]. As presented in Fig. (3), both the samples exhibited peaks that are due to the presence of both $\mathrm{Ce}^{4+}$ and $\mathrm{Ce}^{3+}$ ions, thus implying that cerium is present at the surface in both $4+$ and $3+$ oxidation states in both the samples. The binding energy values presented in Table 2 are in well agreement with the literature reports [11]. The shift in the binding energy to higher values in case of the sample prepared by microwave method may be due to better reducibility of the sample. The Ce/Zr atomic ratios presented in the Table 2 also clearly indicated that the microwave synthesized sample has a more extended incorporation of zirconium into the ceria lattice in comparison to the sample prepared by coprecipitation method, corroborating with the XRD and RS results. The amount of $\mathrm{Ce}^{3+}$ present is determined by calculating the area under the peaks $u^{\prime}$ and $v^{\prime}$ to the total area and the values are presented in Table 2 . These estimations reveal clearly that the ceria-zirconia sample prepared by microwave method contains more amount of $\mathrm{Ce}^{3+}(23 \%)$ when compared to the sample prepared by the coprecipitation method (15\%). High temperature preparation conditions and incorporation of more zirconium into the cubic ceria lattice may be responsible for the observed better reducibility in the case of MW sample in comparison to the CP sample.

Morphology and microstructure of both samples was investigated by TEM technique and a representative image of the MW sample is shown in Fig. (4). The TEM image revealed nanometer sized particles with broad particle size distribution (10-40 nm). The broad particle size distribution could be due to the preparation method adopted. During the preparation, the precursors were exposed to higher temperatures for a short period of time, which obviously leads to particles with different sizes. The digital diffraction pattern (DDP) corresponding to an individual particle of the image is shown in inset of Fig. (4). The inter planar spacing values of 3.0, 2.6, and 3.0 $\AA$ were measured from the DDP and could be respectively assigned to (111), (200), and (1-1-1) family planes of the cubic structure. As per previous literature reports $[37,38]$, the electron diffraction pattern of fluorite cubic structure is characterized by the presence of first three electron diffraction rings which correspond to the inter planar spacings of ca. 3.1 (111), 2.7 (200) and 1.9 (220) ̊. The other two likely phases, tetragonal and monoclinic, exhibit electron diffraction rings at or very close to these cubic spacings, as well as additional reflections. The additional spacings for the tetragonal phase are at 2.1 and possibly at 2.3, 3.7 and $5.3 \AA$ (the last three being possibly active kinetic extinctions) and for the monoclinic at 2.0, 2.3, 3.7 and $5.1 \AA$. These spacings should be treated as approximate since they will vary slightly with the $\mathrm{Zr}$ content in the sample. For example, the spots at 5.3 and $5.1 \AA$ would be difficult to separate unambiguously. The absence of any of these additional spacings clearly indicated that the $\mathrm{Ce}-\mathrm{Zr}$-oxide system exists in the cubic only modification. Taking into account the slight contraction of crystal lattice expected by a partial substitution of $\mathrm{Ce}^{4+}$ ions by smaller $\mathrm{Zr}^{4+}$ ions, the simple fluorite type DDPs are quite obvious [37, 39]. On the whole, the $\mathrm{Ce}_{x} \mathrm{Zr}_{1-x} \mathrm{O}_{2}$ samples exhibited patterns of cubic phase structures only.

Table 2. XPS Data (eV) Obtained for the Ceria-Zirconia Solid Solutions Prepared by Microwave Combustion (MW) and Coprecipitation (CP) Methods

\begin{tabular}{|c|c|c|c|c|c|c|}
\hline Sample & O 1s & $\operatorname{Zr} 3 d_{5 / 2}$ & $\operatorname{Ce~} 3 d_{5 / 2}$ & $\operatorname{Ce~} 3 d_{5 / 2}$ & Amount of $\mathrm{Ce}^{3+}(\%)$ & $\mathrm{Ce} / \mathrm{Zr}$ Atomic Ratio \\
\hline MW & 530.3 & 182.3 & 882.7 & 882.7 & 23.288 & 3.46 \\
\hline $\mathrm{CP}$ & 530.1 & 182.2 & 882.5 & 882.5 & 15.330 & 4.04 \\
\hline
\end{tabular}




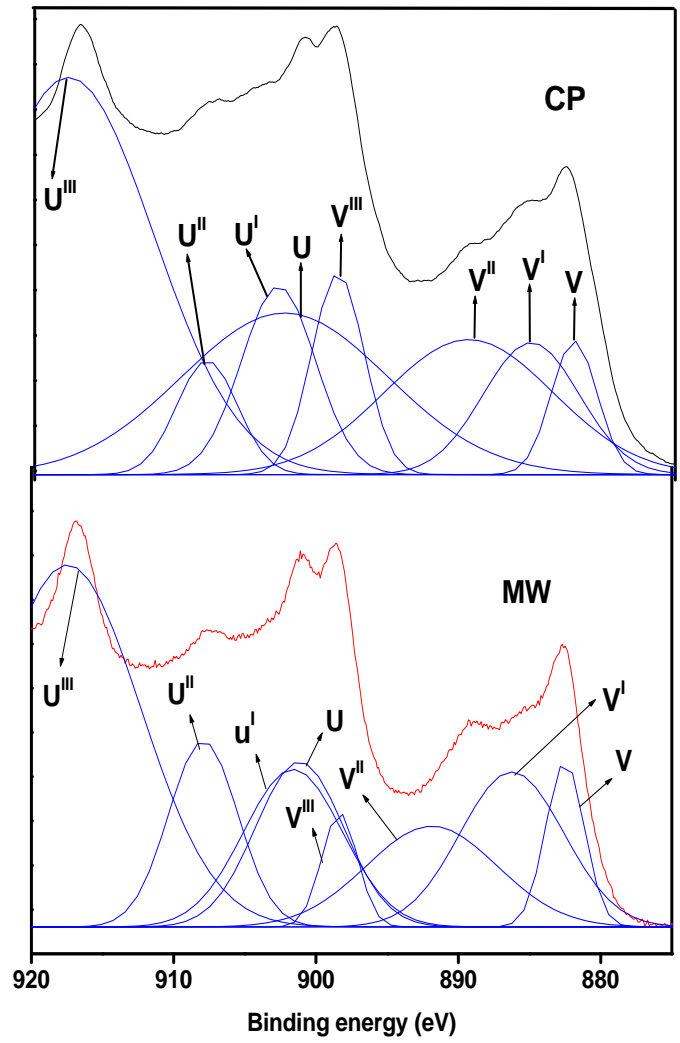

Fig. (3). Ce 3d XPS spectra of ceria-zirconia solid solutions (MW: prepared by microwave method; CP: prepared by coprecipitation method).

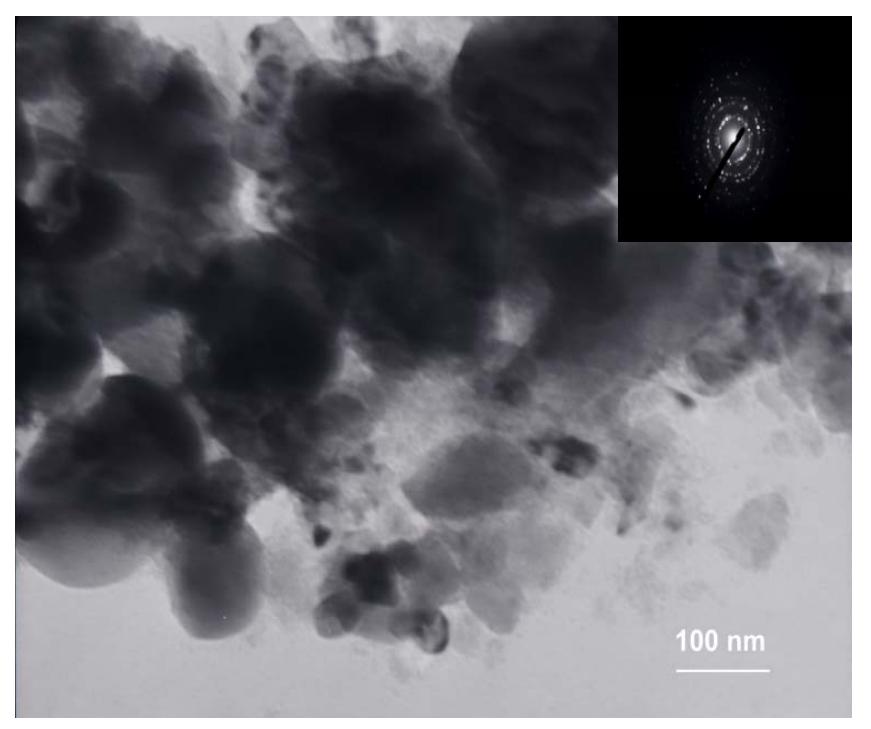

Fig. (4). TEM image of ceria-zirconia solid solution prepared by microwave-assisted combustion synthesis method.

The OSC properties of both the samples were evaluated by thermogravimetry method. Thus obtained oxygen vacancy concentration or storage capacity pertaining to both the samples is shown in Table 1. As presented in Table 1, the MW sample exhibited more OSC than the CP sample. The observed more OSC is mainly due to incorporation of more zirconium and creation of more oxygen vacancies at higher preparation temperatures. The presence of Raman band at $305 \mathrm{~cm}^{-1}$ and more intense band at $600 \mathrm{~cm}^{-1}$ also supports this observation. The CO oxidation results of MW and CP samples as a function of reaction temperature are shown in Fig. (5). As observed from Fig. (5), the MW sample exhibited more $\mathrm{CO}$ conversion than $\mathrm{CP}$ even at a lower temperature. Light-off phenomenon was observed for both the catalysts. Note that light-off means a jump of the activity to over $50 \%$ conversion very quickly, and this characteristic is very important for automobile emission control. The MW sample reached a light-off (50\% conversion) temperature $40 \mathrm{~K}$ lower than that of the CP sample. Furthermore, the MW sample exhibited $100 \%$ CO conversion at $750 \mathrm{~K}$, whereas the CP showed $85 \%$ conversion at $773 \mathrm{~K}$, the highest temperature investigated. The observed more conversion could be due to increased oxygen mobility in the defective fluorite structure of MW sample generated by introduction of more $\mathrm{Zr}^{4+}$ cations into the ceria core lattice compared to the $\mathrm{CP}$.

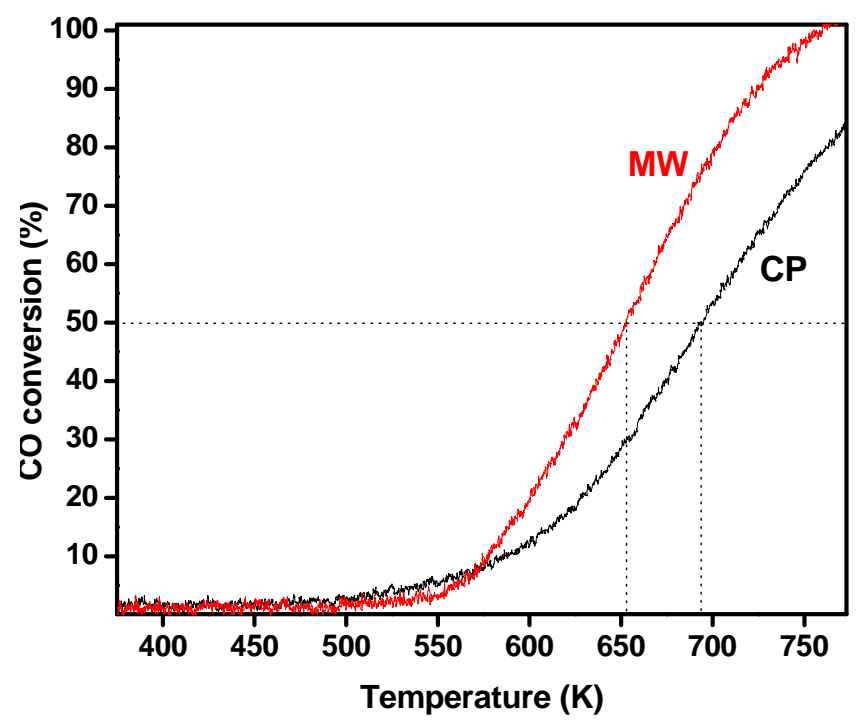

Fig. (5). Conversion of $\mathrm{CO}$ versus temperature profiles of ceriazirconia solid solutions (MW: prepared by microwave method; CP: prepared by coprecipitation method).

\section{CONCLUSIONS}

Nanosized ceria-zirconia solid solution has been synthesized by a microwave-assisted solution combustion synthesis method and compared with that of the ceria-zirconia with the same composition but prepared by a coprecipitation method and calcined at $773 \mathrm{~K}$. The results of XRD and cell parameter values revealed that more zirconium is incorporated into the ceria lattice and more defective sites are formed in the case of microwave-synthesized sample. Raman spectroscopic measurements suggested the presence of oxygen vacancies, lattice defects and displacement of oxygen ions from their ideal lattice positions. TEM results accomplished the presence of nanosized particles in the MW sample. Better oxygen storage capacity and better $\mathrm{CO}$ oxidation activity were observed for the MW sample in comparison to that of $\mathrm{CP}$ sample. In summary, it can be concluded that synthesis of nanosized ceria-zirconia solid solutions by microwaveassisted method is a cost effective technique in comparison to the conventional coprecipitation route for making of catalysts for $\mathrm{CO}$ oxidation. 


\section{ACKNOWLEDGMENTS}

GKR thank UGC, New Delhi for senior research fellowship and LHR thank CSIR, New Delhi for a junior research fellowship.

\section{REFERENCES}

[1] Min, K.; Song, M.W.; Lee, C.H. Catalytic carbon monoxide oxidation over $\mathrm{CoO}_{\mathrm{x}} / \mathrm{CeO}_{2}$ composite catalysts. Appl. Catal. A: Gen., 2003, 251, 143-156.

[2] Song, K.S.; Klvana, D.; Kirchnerova, J. Kinetics of propane combustion over $\mathrm{La}_{0.66} \mathrm{Sr}_{0.34} \mathrm{Ni}_{0.3} \mathrm{Co}_{0.7} \mathrm{O}_{3}$ perovskite. Appl. Catal. A: Gen., 2001, 213, 113-121.

[3] Zamostny, P.; Belohlav, Z. Identification of kinetic models of heterogeneously catalyzed reactions. Appl. Catal. A: Gen., 2002, 225, 291-299.

[4] Baldi, M.; Finocchio, E.; Milella, F.; Busca, G. Catalytic combustion of $\mathrm{C}_{3}$ hydrocarbons and oxygenates over $\mathrm{Mn}_{3} \mathrm{O}_{4}$. Appl. Catal. B: Environ., 1998, 16, 43-51.

[5] Burgos, N.; Paulis, M.; Antxustegi, M.M.; Montes, M. Deep oxidation of VOC mixtures with platinum supported on $\mathrm{Al}_{2} \mathrm{O}_{3} / \mathrm{Al}$ monoliths. Appl. Catal. B: Environ., 2002, 38, 251-258.

[6] Naydenov, A.; Stoyanova, R.; Mehandjiev, D. Ozone decomposition and $\mathrm{CO}$ oxidation on $\mathrm{CeO}_{2} . J$. Mol. Catal., 1995, 98, 9-14.

[7] Trovarelli, A. Catalysis by Ceria and Related Materials, Catalytic Science Series; World Scientific Publishing Company: London, 2002, Vol. 2.

[8] Kaspar, J.; Fornasiero, P.; Graziani, M. Use of $\mathrm{CeO}_{2}$-based oxides in the three-way catalysis. Catal. Today, 1999, 50, 285-298.

[9] Clark, D.E.; Amad. I; Dalton, R.C. Microwave ignition and combustion synthesis of composites. Mater. Sci. Eng. A., 1991, 144, 9197.

[10] Ganesh, I.; Johnson, R.; Mahajan, Y.R.; Khan, A.; Madhavendra, S.S.; Reddy, B.M. Microwave-induced combustion synthesis of nanocrystalline $\mathrm{TiO}_{2}-\mathrm{SiO}_{2}$ binary oxide material. J. Mater. Res., 2004, 19, 1015-1023.

[11] Reddy, B.M.; Khan, A.; Yamada, Y.; Kobayashi, T.; Loridant, S.; Volta, J.C. Raman and X-ray photoelectron spectroscopy study of $\mathrm{CeO}_{2}-\mathrm{ZrO}_{2}$ and $\mathrm{V}_{2} \mathrm{O}_{5} / \mathrm{CeO}_{2}-\mathrm{ZrO}_{2}$ Catalysts. Langmuir, 2003, 19, 3025-3030.

[12] Klug, H.P.; Alexander, L.E. X-ray Diffraction Procedures for Polycrystalline and Amorphous Materials, $2^{\text {nd }}$ ed.; John Wiley and Sons: New York, 1974.

[13] Reddy, B.M.; Khan, A. Nanosized $\mathrm{CeO}_{2}-\mathrm{SiO}_{2}, \mathrm{CeO}_{2}-\mathrm{TiO}_{2}$, and $\mathrm{CeO}_{2}-\mathrm{ZrO}_{2}$ mixed oxides: influence of supporting oxide on thermal stability and oxygen storage properties of ceria. Catal. Surv. Asia, 2005, 9, 155-171.

[14] Wagner, C.D.; Riggs, W.M.; Davis, L.E.; Moulder, J.F. In Handbook of X-ray Photoelectron Spectroscopy; Muilenberg, G. E., Ed.; Perkin-Elmer Corporation: Eden Prairie, MN, 1978.

[15] Reddy, B.M.; Lakshmanan, P.; Bharali, P.; Saikia, P.; Thrimurthulu, G.; Muhler, M.; Grünert, W. Influence of alumina, silica, and titania supports on the structure and $\mathrm{CO}$ oxidation activity of $\mathrm{Ce}_{\mathrm{x}} \mathrm{Zr}_{1-\mathrm{x}} \mathrm{O}_{2}$ nanocomposite oxides. J. Phys. Chem. C, 2007, 111, 10478-10483.

[16] Kenevey, K.; Valdivieso, F.; Soustelle, M.; Pijolat, M. Thermal stability of $\mathrm{Pd}$ or $\mathrm{Pt}$ loaded $\mathrm{Ce}_{0.68} \mathrm{Zr}_{0.32} \mathrm{O}_{2}$ and $\mathrm{Ce}_{0.50} \mathrm{Zr}_{0.50} \mathrm{O}_{2}$ catalyst materials under oxidizing conditions. Appl. Catal. B: Environ., 2001, 29, 93-102.

[17] Bernal, S.; Kaspar, J.; Trovarelli, A. Preface. Catal. Today (Special Issue), 1999, 50, 173

[18] Putna, E.S.; Vohs, J.M.; Gorte, R.J. Evidence for weakly bound oxygen on ceria films. J. Phys. Chem., 1996, 100, 17862-17865.

[19] Meriani, S.; Spinolo, G. Powder data for metastable $\mathrm{Zr}_{x} \mathrm{Ce}_{1-\mathrm{x}} \mathrm{O}_{2}(\mathrm{x}=$ 0.84 to 0.40 ) solid solutions with tetragonal symmetry. Powder Diffraction J., 1987, 2, 255-256.

[20] Esch, F.; Fabris, S.; Zhou, L.; Montini, T.; Africh, C.; Fornasiero, P.; Comelli, G.; Rosei, R. Electron localization determines defect formation on ceria substrates. Science, 2005, 309, 752-755.
Martinez-Arias, A.; Fernandez-Garcia, M.; Ballesteros, V.; Salamanca, L.N.; Conesa, J.C.; Otero, C.; Soria, J. Characterization of high surface area $\mathrm{Zr}-\mathrm{Ce}(1: 1)$ mixed oxide prepared by a microemulsion method. Langmuir, 1999, 15, 4796-4802.

[22] Lin, X.-M.; Li, L.-P.; Li, G.-S.; Su, W.-H. Transport property and Raman spectra of nanocrystalline solid solutions $\mathrm{Ce}_{0.8} \mathrm{Nd}_{0.2} \mathrm{O}_{2-\delta}$ with different particle size. Mater. Chem. Phys., 2001, 69, 236-240. Spanier, J.E.; Robinson, R.D.; Zhang, F.; Chan, S.-W.; Herman, I.P. Size-dependent properties of $\mathrm{CeO}_{2-y}$ nanoparticles as studied by Raman scattering Phys. Rev. B., 2001, 64, 245407.

[24] Weber, W.H.; Hass, K.C.; McBride, J.R. Raman study of $\mathrm{CeO}_{2}$ second-order scattering, lattice dynamics, and particle-size effects. Phys. Rev. B, 1993, 48, 178-185.

[25] Reddy, B.M.; Lakshmanan, P.; Khan, A.; Loridant, S.; Cartes, C.L.; Rojas, T.C.; Fernandez, A. Surface stabilized nanosized $\mathrm{Ce}_{\mathrm{x}} \mathrm{Zr}_{1-\mathrm{x}} \mathrm{O}_{2}$ solid solutions over $\mathrm{SiO}_{2}$ : characterization by XRD, Raman, and HREM techniques. J. Phys. Chem. B., 2005, 109, 13545-13552.

[26] McBride, J.R.; Hass, K.C.; Poindexter, B.D.; Weber, W.H. Raman and $x$-ray studies of $\mathrm{Ce}_{1-\mathrm{x}} \mathrm{RE}_{\mathrm{x}} \mathrm{O}_{2-\mathrm{y}}$, where $\mathrm{RE}=\mathrm{La}, \mathrm{Pr}, \mathrm{Nd}, \mathrm{Eu}, \mathrm{Gd}$, and Tb. J. Appl. Phys., 1994, 76, 2435-2441.

[27] Escribano, V.S.; Lopez, E.F.; Panizza, M.; Resini, C.; Amores, J.M.G.; Busca, G. Characterization of cubic ceria-zirconia powders by X-ray diffraction and vibrational and electronic spectroscopy. Solid State Sci., 2003, 5, 1369-1376.

[28] Vlaic, G.; Fornasiero, P.; Geremia, S.; Kaspar, J.; Graziani, M. Relationship between the Zirconia-Promoted Reduction in the RhLoaded $\mathrm{Ce}_{0.5} \mathrm{Zr}_{0.5} \mathrm{O}_{2}$ Mixed Oxide and the $\mathrm{Zr}-\mathrm{O}$ Local Structure. $J$. Catal., 1997, 168, 386-392.

[29] Yashima, M.; Arashi, H.; Kakihana, M.; Yoshimura, M. Raman scattering study of cubic-tetragonal phase transition in $\mathrm{Zr}_{1-\mathrm{x}} \mathrm{Ce}_{\mathrm{x}} \mathrm{O}_{2}$ solid solution. J. Am. Ceram. Soc., 1994, 77, 1067-1071.

[30] Bensalem, A.; Bozon-Verduraz, F.; Delamar, M.; Bugli, G. Preparation and characterization of highly dispersed silica-supported ceria. Appl. Catal. A: Gen., 1995, 121, 81-93.

[31] Paparazzo, E.; Ingo, G.M.; Zacchetti, N. X-ray induced reduction effects at $\mathrm{CeO}_{2}$ surfaces: an x-ray photoelectron spectroscopy study. J. Vac. Sci. Technol. A., 1991, 9, 1416-1420.

[32] Praline, G.; Koel, B.E.; Hance, R.L.; Lee, H.-I.; White, J.M. X-Ray photoelectron study of the reaction of oxygen with cerium. J. Electron Spectrosc. Relat. Phenom., 1980, 21, 17-30.

[33] Pfau, A.; Schierbaum, K.D. The electronic structure of stoichiometric and reduced $\mathrm{CeO}_{2}$ surfaces: an XPS, UPS and HREELS study. Surf. Sci., 1994, 321, 71-80.

[34] Galtayries, A.; Sporken, R.; Riga, J.; Blanchard, G.; Caudano, R. XPS comparative study of ceria/zirconia mixed oxides: powders and thin film characterisation. J. Electron Spectrosc. Relat. Phenom., 1998, 88-91, 951-956.

[35] Briggs, D.; Seah, M.P. Practical Surface Analysis: Auger and XRay Photoelectron Spectroscopy, $2^{\text {nd }}$ ed.; Wiley: New York, 1990, Vol. 1 .

[36] Burroughs, A.; Hamnett, A.; Orchard, A.F.; Thornton, G. Satellite structure in the $\mathrm{X}$ ray photoelectron spectra of some binary and mixed oxides of lanthanum and cerium J. Chem. Soc. Dalton Trans., 1976, 1, 1686-1697.

[37] Colon, G.; Pijolat, M.; Valdivieso, F.; Vidal, H.; Kaspar, J.; Finocchio, E.; Daturi, M.; Binet, C.; Lavalley, J.C.; Baker, R.T.; Bernal, S. Surface and structural characterization of $\mathrm{Ce}_{\mathrm{x}} \mathrm{Zr}_{1-\mathrm{x}} \mathrm{O}_{2}$ CEZIRENCAT mixed oxides as potential three-way catalyst promoters. J. Chem. Soc. Faraday Trans., 1998, 94, 3717-3726.

[38] Colon, G.; Valdivieso, F.; Pijolat, M.; Baker, R.T.; Calvino, J.J. Bernal, S. Textural and phase stability of $\mathrm{Ce}_{\mathrm{x}} \mathrm{Zr}_{1-\mathrm{x}} \mathrm{O}_{2}$ mixed oxides under high temperature oxidizing conditions. Catal. Today, 1999, $50,271-280$.

[39] Reddy, B.M.; Khan, A.; Yamada, Y.; Kobayashi, T.; Loridant, S.; Volta, J.C. Structural characterization of $\mathrm{CeO}_{2}-\mathrm{MO}_{2}\left(\mathrm{M}=\mathrm{Si}^{4+}\right.$ $\mathrm{Ti}^{4+}$, and $\mathrm{Zr}^{4+}$ ) mixed oxides by Raman spectroscopy, X-ray photoelectron spectroscopy, and other techniques. J. Phys. Chem. B, 2003, 107, 11475-11480.

Received: May 08, $2009 \quad$ Revised: May 16, $2009 \quad$ Accepted: May 18, 2009

(C) Reddy et al.; Licensee Bentham Open.

This is an open access article licensed under the terms of the Creative Commons Attribution Non-Commercial License (http://creativecommons.org/licenses/by-nc/3.0/) which permits unrestricted, non-commercial use, distribution and reproduction in any medium, provided the work is properly cited. 